\title{
The Five Star Movement: Exception or Vanguard in Europe?
}

\section{Lorenzo Mosca}

\begin{abstract}
The enduring economic crisis, austerity measures and corruption scandals have created a favourable environment for the advent of new political actors all over Europe. During the last general elections (February 2013), Italy was shocked by the inexorable rise of the Five Star Movement. Beppe Grillo's creature upset the political system, occupying portions of the public sphere that had been ignored (the web) or gradually abandoned by traditional political parties (the squares). Its unusual campaigning style, its internet-based organisational structure, its atypical political positioning (beyond left and right), and its oversimplification of complex problems all help to explain its electoral performance, and distinguish it from similar anti-establishment parties that have emerged in Europe over the past decade.
\end{abstract}

Keywords: Five Star Movement, anti-politics, window of opportunity, internal democracy

Contemporary political systems are seriously challenged by changes occurring both at the supranational and at the national level. Globalisation has thrown into question not only the role of the nation state, but also and more generally, the capacity of politics to intervene in the economy and regulate social conflict. ${ }^{1}$ Recently, this has been further worsened by the economic crisis as citizens blame the European Union and governing parties for austerity measures that have led to cuts in social spending, unemployment and higher taxation. At the same time, the mediatisation of politics ${ }^{2}$ has deeply affected domestic politics transforming them into a show observed passively by citizens in which parties have been replaced by leaders, organisation by television, and ideology by marketing. ${ }^{3}$ Political corruption and scandals exposed by the media have increased people's cynicism and detachment from politics.

Available Eurobarometer data collected since the end of 2003 clearly show that a process of disenchantment toward traditional politics and institutions is at work in

\footnotetext{
Lorenzo Mosca is Assistant Professor at Roma Tre University. Email: lorenzo.mosca@uniroma3.it

${ }^{1}$ Crouch, Post-democracy.

${ }^{2}$ Mazzoleni and Schulz, "'Mediatization' of Politics".

${ }^{3}$ Manin, Principles of representative government.
} 


\section{L. Mosca}

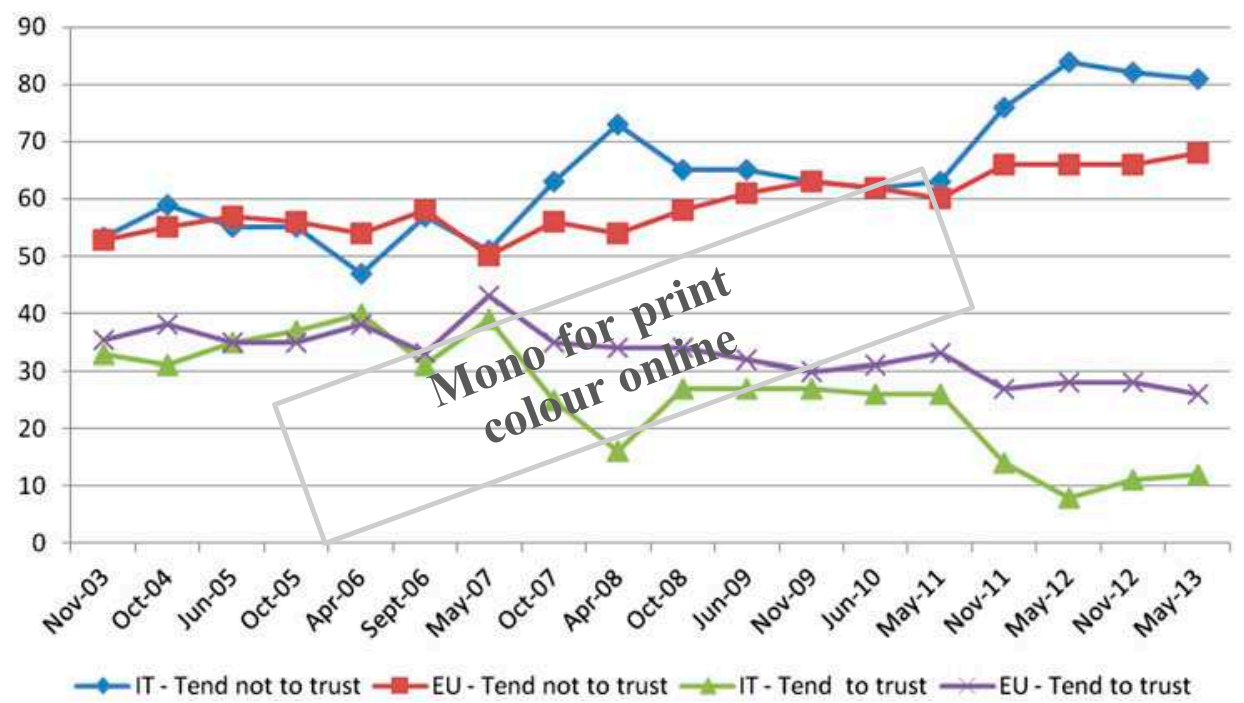

FIGURE 1. Trust in parliaments (percentages; Italy vs. European average).

Source: Eurobarometer (2003-13).

all member states of the European Union (EU). ${ }^{4}$ Data display an evident trend of declining trust in national parliaments, national governments and domestic political parties (Figures 1-3). However, when confronted with average levels of trust in the $\mathrm{EU}$, the Italian case appears even more dramatic. In fact, trust in the national parliament is around 12 percent $(-19$ since the start of the observation period and -14 during the past year) vs. the EU average of 26 percent ( -9 in the last decade), trust in the national government is around 11 percent ( -16 since the start of the observation period and -13 during the past year) vs. the EU average of 25 percent ( -6 in the last decade) and trust in political parties is around 7 percent $(-4$ since the start of the observation period) vs. the EU average of 16 percent $(+1$ in the past decade).

The corruption scandals of the early 1990s (Mani Pulite - Clean Hands) as well as recent cases that have troubled all Italian parties, including those with an antiestablishment rhetoric and opposing corruption, such as Lega Nord and Italia dei

15 Valori, have further decreased trust in traditional political parties. ${ }^{5}$

At the beginning of 2012, the treasurers of some of the main Italian parties were put under investigation for illicit use of electoral reimbursements: among them were Luigi Lusi (Margherita, one of the founding members of the Democratic Party) and Francesco Belsito (Lega Nord). In September 2012, both Franco Fiorito,

20 leader of the Popolo della Libertà (PDL) group in the Lazio Regional Council, and the Lazio regional government led by Renata Polverini were swept away by scan-

${ }^{4}$ http://ec.europa.eu/public_opinion/cf/index_en.cfm.

${ }^{5}$ Fella and Ruzza, "Populism and the Fall"; Mosca, "A year of social movements". 


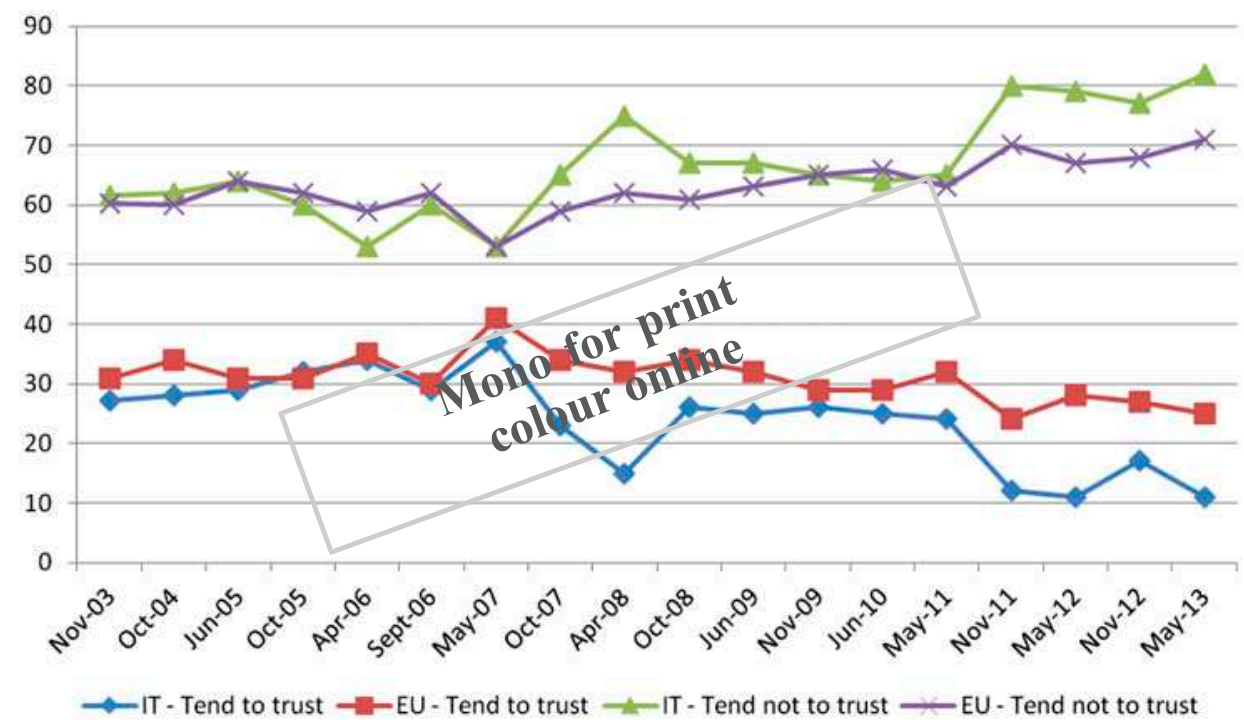

FIGURE 2. Trust in national governments (percentages; Italy vs. European average).

Source: Eurobarometer (2003-13).

dals linked to the improper use of public funds, while in October of the same year, the regional centre-right government headed by Roberto Formigoni in Lombardy was forced to suspend the legislature prematurely due to the involvement of some of its members in cases of corruption, pork barrelling and external collusion with the Mafia. An inquiry aired by the TV program 'Report' on October 28 revealed Antonio di Pietro's unscrupulous use of electoral reimbursements assigned to his party, Italia dei Valori. Together with these events, parliament's inability to change the electoral law and to significantly reduce the cost of politics have further discredited political parties. Between April and May 2013, dozens of regional counsellors in different regional assemblies (Campania, Calabria, Basilicata, Friuli-Venezia Giulia, Veneto) were brought under investigation for improper use of public funds.

This situation opened up opportunities for outsiders in the political arena, and these were grasped by an unusual political entrepreneur: the comedian Beppe Grillo and his Five Star Movement (FSM). Although the Italian case certainly has specificities vis-à-vis other European countries, political phenomena that can be paralleled to the Five Star Movement had already emerged in other Western democracies in past decades. The case of the French comedian Coluche running for president at the beginning of the 1980s has often been recalled. ${ }^{6}$ More recently, after the tremendous financial crisis of 2008, a well known comedian, Jon Gnarr, was elected mayor of Reykjavik, in Iceland, with his Best Party collecting 34.7 percent of the votes. ${ }^{7}$

\footnotetext{
${ }^{6}$ Biorcio and Natale, Politica a 5 stelle.

${ }^{7}$ Boyer, "Simply the Best".
} 


\section{$4 \quad$ L. Mosca}

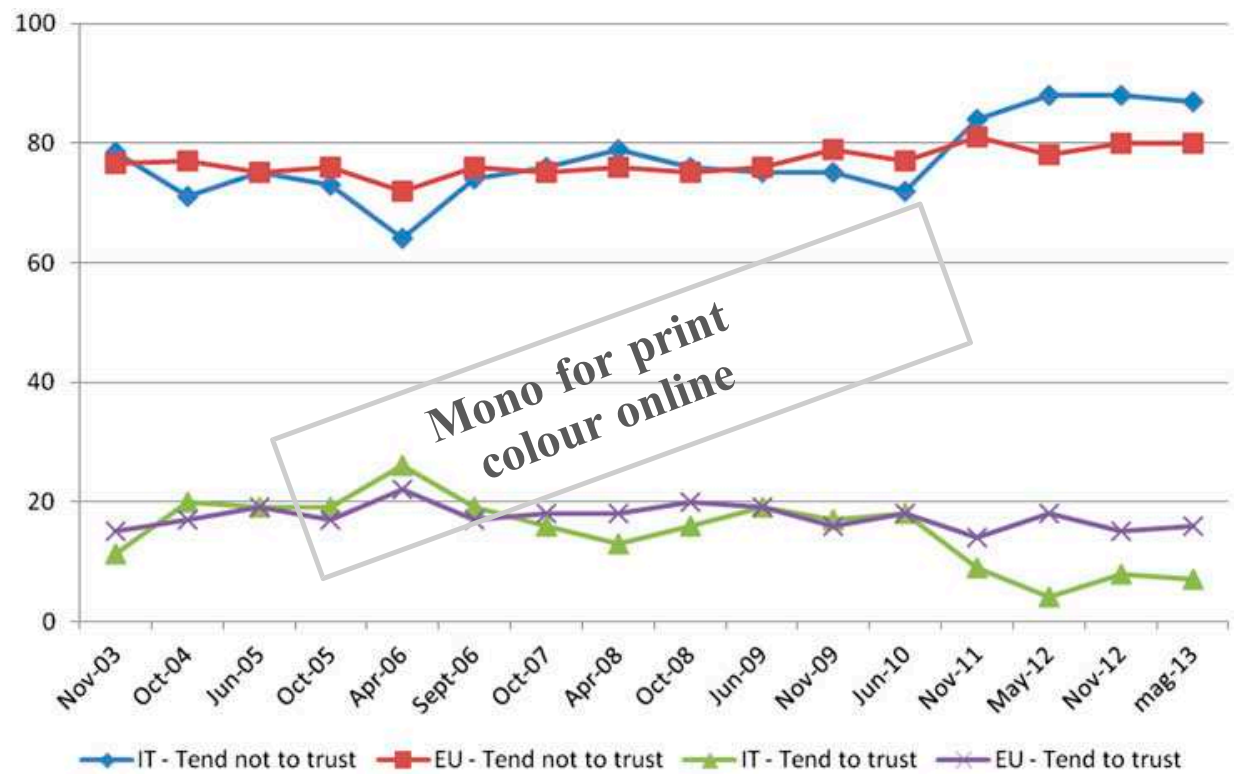

Figure 3. Trust in political parties (percentages; Italy vs. European average).

Source: Eurobarometer (2003-13).

Beyond cases of comedians entering the political arena, recent elections all over Europe have seen the success of anti-establishment parties at the local and/or national level, such as the euro-sceptic United Kingdom Independence Party (UKIP) in the UK, the radical left party Syriza and the radical right party Golden Dawn in Greece, and the Piraten Partei and Alternative für Deutschland in Germany (neither of which were however able to enter the Bundestag in the September 2013 federal elections). Other new political parties continue to arise in Europe, such as, the X Party Citizen Network - the Party of the Future, which aims to pick up the legacy of the Indignados movement in Spain and whose unique program is "Democracy, full stop".

Nevertheless, while the Five Star Movement has some features in common with this new generation of political parties, it is also distinct from most of them for its position beyond left and right and for its unusual organisational form, which is heavily based on the web.

This article will provide a brief overview of how and when the Five Star Movement arose, its differences and similarities with other anti-establishment groups in Europe, and its prospects for the future. 


\section{The rising stars}

Grillo is a well known Italian comedian who became famous with his television shows at the end of the seventies. During the 1980s, he was banned from public television because of satire against the governing Socialist Party. He then decided to move his shows to squares and theatres. ${ }^{9}$ His performances have always been a mix of political satire, social and environmental campaigns, consumer defence, etc. After meeting with the communications expert Gianroberto Casaleggio in 2004, he realised the importance of the internet and started a blog in 2005 that became very successful. Initially, the blog represented an important hub for his fans all over the country. In July 2005, he suggested that his supporters create local groups using the Meetup platform. ${ }^{10}$ As explicitly recognised by Casaleggio, ${ }^{11}$ this choice was inspired by the American group MoveOn. ${ }^{12}$

Politics rapidly moved from the background to the foreground of Grillo's discourse and his fans were quickly transformed into activists ${ }^{13}$ who could easily meet in person and define a local agenda. ${ }^{14}$ These groups were the basic cells that facilitated the emergence of the FSM a few years later.

The FSM's organisational model presents some of the "post-bureaucratic" characteristics that have been stressed by Bruce Bimber, ${ }^{15}$ in describing the emerging groups of the "fourth information revolution", generated by the advent of digital media. Essentially, "post-bureaucratic" groups are based on an information infrastructure that replaces a material organisational infrastructure. The FSM's immaterial infrastructure is basically the blog and the Meetup platform (social networks like Facebook and Twitter were added later on).

The movement has clearly adopted some of the tactical innovations introduced by MoveOn: a small coordinating staff, no offices, use of the internet for organisational purposes, decision-making and fundraising. However, the two groups differ in their relationship with members. While MoveOn opted for an open and inclusive model (it is enough to subscribe to its online newsletter to be considered a member), the FSM has adopted a closed and exclusive model (one has to subscribe formally to the blog to become a member, sending a digital copy of an identity

\footnotetext{
${ }^{9}$ Vignati, "Challenge of Five-Star Movement".

${ }^{10}$ Meetup is an online platform created in 2001 , after $9 / 11$, to connect people with similar interests on a local scale. Its political potential emerged with the American presidential elections in 2004 when the democratic candidate, Howard Dean, employed it to encourage bottom-up participation in his campaign during the primaries.

${ }^{11}$ http://www.youtube.com/watch?v=wwp32DDRrck.

${ }^{12} \mathrm{MoveOn}$ is an American advocacy group which started in 1998 as an online petition aimed at censuring President Clinton's involvement in the 'sex gate' affair and moving attention to other pressing issues. Since then, it has built an internet-based community of more than 8 million Americans and become the leading progressive organisation. It played an important role in Obama's election (www.front.moveon.org/about). Karpf, The MoveOn Effect.

${ }^{13}$ Biorcio and Natale, Politica a 5 stelle.

${ }^{14}$ Lanfrey, "Il MoVimento dei grillini".

${ }^{15}$ Bimber, Information and American Democracy.
} 


\section{L. Mosca}

card to the staff and declaring compliance with the 'non-statute' which excludes anyone who is already a member of another political party or association whose goals contrast with those of the movement). The current figures for members are unknown but they were 255,339 at the beginning of December 2012, when the online primaries were held. ${ }^{16}$ There are evident barriers to participation in the

10 movement. Only people registered on the blog can take part in the online consultations concerning its strategic choices: selection of candidates running for parliament, local elections (mayors and local representatives) or the presidency of the republic, as well as the expulsion of dissidents. ${ }^{17}$ Other differences between MoveOn and the FSM concern the charismatic leadership of Grillo, and the salvific conception of the web as an instrument of direct democracy that can help make the egalitarian slogans of the movement come true, both of which are absent in the former. According to Grillo and Casaleggio, ${ }^{18}$ the internet is an instrument of "disintermediation" between citizens and institutions, making it possible to bypass typical mediators of representative democracy (such as political parties, trade unions, etc.) and overcome the partisanship and factionalism of professional journalists and mainstream media (particularly newspapers and television).

While MoveOn represented a clear reference in the early stages of the movement, since then it has adapted itself to the particular set of challenges and opportunities of the national context. From this point of view, the movement's history can be roughly divided into four phases: a) latency (2005-07); b) visibility (2007-08); c) entry into the electoral arena (2008-11); d) electoral boom and institutionalisation (since 2012). ${ }^{19}$

\section{Phase 1: Latency in the web (2005-07)}

The phase of latency started when Grillo set up his blog in January 2005 and invited his fans to create groups on Meetup called "Beppe Grillo's friends" in the same year. While the blog was the movement's unique voice, the Meetup groups served as its territorial backbone. In this phase, Grillo gradually put aside his role as a comedian and became a political entrepreneur. ${ }^{20}$ At the same time, supporter groups started to form on Meetup and get to know each other. Meetup provided a locus for the aggregation of Grillo's fans, for staying in contact and for promoting projects of active citizenship in the local domain. Public visibility and media coverage of the movement were extremely limited at this phase and the new (pre)politi-

\footnotetext{
${ }^{16}$ Lanzone, "Dai Meetup al Parlamento".

${ }^{17}$ Unlike MoveOn, online consultations have never been used by the FSM to consult its base on substantial issues (i.e. controversial long-term issues or bills to be discussed in local or national assemblies).

${ }^{18}$ Grillo and Casaleggio, Siamo in guerra.

${ }^{19}$ Mosca, La webpolitica.

${ }^{20}$ Biorcio and Natale, Politica a 5 stelle.
} 


\section{Five Star Movement: Exception or Vanguard?}

cal creature was known only to the limited circuit of supporters and activists. According to Passarelli et al., ${ }^{21}$ the role of Meetup changed considerably from the first to the second phase: while it acted mostly as a platform for online discussion during the former, during the latter it facilitated activists' face-to-face meetings.

\section{Phase 2: Visibility through mass protests (2007-08)}

During this phase, Grillo's fans moved from the web and the local domain to the squares, and their mobilisation acquired national resonance. Two massive public events were organised through the internet and mobilised hundreds of thousands of people. These events generated attention and (often negative) media coverage legitimising this new political actor (still far from forming a political party to compete in the electoral arena). The two events were called 'V-days' for different reasons: a) V stands for Vaffanculo (f*** off), an insult directed at politicians and journalists; b) V also recalls a famous graphic novel by Alan Moore and David Lloyd, $V$ for Vendetta, set in a futuristic UK after a nuclear war led by a totalitarian government opposed by the anonymous anarchist revolutionary ' $\mathrm{V}$ '; c) V-day also recalls the 'D-day' landing of the Allies in Normandy during the Second World War; and finally d) V stands for ' 5 ' in Roman numerals and refers to the five stars (water, environment, mobility, development, energy) that Grillo and his supporters think should inspire local governments' action (see next section for more details). These protest events served to define and provide a concrete reference to the movement's fluid identity and to build a sense of solidarity among participants beyond the local level, also by pointing to the "enemies" of the movement: above all, traditional political parties and mainstream media.

On 8 September $2007,,^{22}$ the first V-day against the "caste of politicians" was held in Bologna and in other Italian cities to collect signatures for a popular law initiative demanding a "clean parliament". It called for a ban from parliament of all persons convicted; reform of the electoral system allowing voters to express preferences for individual candidates; a limit of two terms in parliament; and the prohibition to hold two elected posts at the same time. On 25 April 2008, ${ }^{23}$ the second V-day against the "caste of journalists" took place in Turin and in other Italian squares collecting signatures for a popular law initiative to abolish subsidies to the publishing industry, cancel the Gasparri Law (regulating the media system) via a referendum, and eliminate the official journalist register. In both cases, the initiatives collected hundreds of thousands of signatures but were not taken into consideration by the Italian parliament. After the success of the first V-day, Grillo proposed that his supporters set up civic lists "certified" by him and his staff to

\footnotetext{
${ }^{21}$ Passarelli et al., "Dentro il Movimento".

${ }^{22} \mathrm{~A}$ date evoking the armistice between the Kingdom of Italy and the 'Allies' during World War II that symbolised the end of the fascist regime but also opened up a period of chaos in the country.

${ }^{23}$ National holiday recalling the day of liberation from Nazi-Fascism.
} 
participate in local elections. This decision paved the way for the creation of the FSM and its entry into the electoral arena.

\section{Phase 3: Entry into the electoral arena (2008-11)}

Although it did not produce amazing results, the FSM's first attempt to participate in local elections was judged positively by Grillo and his staff. It became immediately evident, however, that in order to expand its electoral appeal, a common symbol and a common name were needed to create a unique reference for Grillo's supporters and to avoid the creation of fake lists evoking the leader's name in their party symbols. ${ }^{24}$ The creation of the FSM was preceded by some important events. First, the approval of the Carta di Firenze (Florence Charter), drafted in a meeting held in Florence on 9 March 2009, in which the people drawing up the certified electoral lists, Grillo's supporters and members of Meetup groups got together to define a common program identifying the main issues that should drive the action of local government - the so-called five stars: water, environment, mobility, development and energy. Second, in July 2009, Grillo provocatively announced that he would run in the centre-left Democratic Party's (DP) primary elections for the new party secretary. Although it is not clear if Grillo really wanted to participate in the primaries, the DP's board did not accept his candidature. On 10 October, the FSM was officially born and two months later a 'non-statute' regulating the functioning of the 'non-party' was made public. ${ }^{25}$ The non-statute clearly underlined the strategic role of the web and also the personalised nature of the FSM, as Grillo was indicated as the sole owner of the logo and the name of the movement. Another interesting aspect of the document concerns the prohibition for people having criminal convictions (Grillo himself ${ }^{26}$ ) to run for election.

The FSM initially participated only in local elections (that is in areas where Meetup groups were already present and able to form a list). In the regional elections of 2010, it obtained positive results in the northern regions but was weak in central-southern areas. $^{27}$

\section{Phase 4: Electoral boom and institutionalisation (since 2012)}

The real turning point in the movement's electoral results came with the local elections of May 2012, when it elected four mayors (one in the city of Parma) and obtained more than 10 percent of votes in many northern areas. ${ }^{28}$ After that

\footnotetext{
${ }^{24}$ In Italian, 'Grillo' means 'cricket' and puns ( with Pinocchio's cricket) have often been used by fake lists to steal the votes of Grillo's supporters.

${ }^{25}$ Fornaro, "Un non-partito".

${ }^{26}$ Grillo has a conviction for manslaughter. The car he was driving on a mountain road in 1980 crashed and three of his four passengers were killed.

${ }^{27}$ Tronconi, "The Italian regional elections".

${ }^{28}$ Pinto and Vignati, "Il successo e i dilemmi".
} 
'electoral boom', the movement's rise seemed unstoppable: it became the most voted party in the Sicilian regional elections of November 2012 and the first party (excluding the votes of Italians residing abroad) in the lower chamber of parliament in the general elections of February 2013.

While the early stages of the movement were mostly web-based, its massive success from 2012 onward was largely related to Grillo's choice to actively campaign in the squares. While he refuses to take part in TV shows (as he considers them part of the immoral system he wants to fight), the mass media could not ignore him as crowds of people participated in his rallies all over the country and because the par condicio law obliges public television to provide equal coverage for all competitors during an electoral campaign.

Concerning the most important aspects of the FSM program, Passarelli et al. ${ }^{29}$ have stressed in particular neo-environmentalism and the moralisation of politics. On the one hand, most of the movement's proposals have been developed with reference to the local level concerning environmental issues. On the other, the movement proposes an anti-establishment discourse against the 'caste' of politicians that is said to enjoy privileges and that should be suppressed. ${ }^{30}$ Hence, the movement asks for a drastic reduction in the cost of politics and a limit on terms in parliament and in local councils in order to give all citizens the possibility to engage in politics for a limited period of time. In this framework, political inexperience is considered a strength rather than a weakness.

With the entry into the national parliament of 163 representatives in February 2013, the movement entered a phase of 'institutionalisation', 31 characterised by tensions mostly related to its fast growth and the unsolved question of the relationship between Grillo (unelected leader) and the movement's representatives. The cohesion of the parliamentary group has been bedevilled by Grillo's brusque refusal to enter into any kind of political alliance (that is a coalition government with the DP), and dissent and/or criticism have been punished with expulsion. In addition, the issues of cuts to the salaries of the movement's own members of parliament (cuts to the salaries of all MPs was part of the party's platform) and of dissidents' expulsion monopolised the FSM's political agenda for a long time, offering an image of conflict among themselves. The local elections of summer 2013 saw the first serious defeat of the FSM with only three mayors elected in minor Italian cities. The result has to be related to the limited effectiveness of the FSM's presence in the national parliament.

\footnotetext{
${ }^{29}$ Passarelli et al., "Dentro il Movimento".

${ }^{30}$ This anti-establishment claim has been made in a very virulent way by Grillo: in his words politicians are "zombies" who steel money and now have to hand over the floor to honest citizens.

${ }^{31}$ Gualmini, "Da movimento a partito”.
} 


\section{The indiscrete charm of anti-politics}

How did this rapid and partly unexpected success come about? How was the movement able to nationalise and gather support from people with different territorial, social and political connotations? There are two main explanations:

1) The first is contextual and strictly related to the incapacity of domestic politics to bring about badly needed reforms (changing the electoral law, suppressing the provinces, cutting the cost of politics, etc.), but also to the continuous scandals exposing corruption in all political parties (including those, such as Lega Nord and Italia dei Valori, that were successful because of their fight against corrupt politics);

2) The second reason concerns the movement's ability to grasp the opportunity to fill the vacuum in the political arena, presenting itself as pure, distinct from traditional parties and uncompromised.

This has been done in a number of ways:

a) Effective electoral campaigns mixing pre-modern and post-modern features: ${ }^{32}$ face-to-face rallies, the active role of activists, low costs covered by online fundraising, but also the use of communications consultants (Casaleggio and his staff) and interactive web platforms; ${ }^{33}$

b) Grillo's ability to occupy portions of the public sphere (the web and the squares) almost ignored by other competitors (mostly focused on television), creating tremendously attractive events for the media: for example, Grillo opened the campaign for the regional elections in Sicily by swimming across the Strait of Messina, while the campaign for the general elections (called 'Tsunami tour') ended up with hundreds of thousands of people listening to him in Piazza San Giovanni in Rome.

c) The use of the Meetup platform as the territorial backbone of a movement initially lacking territorial organisation, media access and material resources. During the phases discussed above, the territorial spread of Meetup groups changed significantly. According to a survey carried out on 1 October 2012, the active groups on Meetup totalled 502: ${ }^{34} 2012$ alone saw the creation of 221 new groups, which amounts to 44 percent of those created since 2005 when Grillo first suggested the adoption of the platform to the movement's activists. The dates on which these groups were set up show that there were different waves, corresponding to the phases mentioned above: latency; visibility (including the entry into the electoral

\footnotetext{
${ }^{32}$ Norris, $A$ virtuous circle.

${ }^{33}$ Mosca and Vaccari, "Il Movimento e la rete".

${ }^{34}$ Mosca, "A year of social movements".
} 
arena); and the electoral boom. During the first phase, 99 groups were formed: one fifth of the total. During the second phase, 201 groups were formed, two-fifths of the total. In the third phase, following the victory in the municipalities of Parma, Mira, Sarego and Comacchio, 182 new groups were created: a remarkable number if one considers that they appeared in the five months spanning the summer, notoriously an adverse time for political engagement. ${ }^{35}$ The geographic distribution of the groups is also worth noting: matching the territorial distribution with the movement's various phases of development gives some very meaningful results. ${ }^{36}$ During the first two phases, the Meetups tended to be concentrated in the north and the 'red' area of Italy (the traditionally leftwing area of the country). These accounted for over 60 percent of Meetups, and corresponded to the places where, over time, the movement achieved its best electoral results. ${ }^{37}$ However, after the May 2012 local elections, the distribution of the Meetups went through some extremely significant changes: almost half of the new groups were formed in the southern regions, that is the area in which the FSM was organisationally and electorally at its weakest. Apparently, a 'bandwagon effect' contributed to reducing the gap between north and south.

d) The peculiar position of this new actor in the political spectrum (declaring itself beyond left and right), which made it a 'catch-all' party in a country where the electorate was still very polarised around the left-right cleavage (anti-communism vs anti-berlusconism) and where voter swings between the opposed coalitions were extremely limited. ${ }^{38}$ As Carbone and Newell put it, "voting in Italy, apparently, has ceased to be an act of faith and has become a means of sanctioning traditional parties". ${ }^{39}$ According to Bordignon and Ceccarini, the current votes for the FSM came in three different waves: firstly from the far and moderate left and the area of abstention (until the local elections of May 2012), then from the right (Lega Nord and Popolo della Libertà; May 2012) and, finally, from the centre-left (general elections; February 2013). ${ }^{40}$ As observed by Ilvo Diamanti, the movement

does away with the distinction between left and right and between north and south, but also between centre and periphery. It is not by chance that it attracts voters from all political and territorial areas ... it has a social interclassist base ... it is the most voted party among entrepreneurs and self-employed workers (44 percent), among the

\footnotetext{
${ }^{35}$ At the time of writing (24 September 2013) the overall number of active groups on Meetup has increased to 1,256 .

${ }^{36}$ The geographic areas taken into consideration are the following: North (Trentino-Alto Adige, Veneto, Friuli-Venezia Giulia, Lombardy, Liguria, Piedmont, Val D'Aosta), red area (Emilia-Romagna, Tuscany, Umbria, Marche), Centre (Lazio, Sardinia, Abruzzo, Molise), South (Campania, Basilicata, Puglia, Calabria, Sicily).

${ }^{37}$ Pinto and Vignati, "Il successo e i dilemmi".

${ }^{38}$ Natale, "Comportamento elettorale: fedeltà leggera".

${ }^{39}$ Carbone and Newell, "The (apparent) calm", 103.

${ }^{40}$ Bordignon and Ceccarini, “Tsunami' a 5 stelle".
} 


\section{L. Mosca}

working class (38 percent) but also among the unemployed (40 percent). Among freelance professionals (32 percent) and students (28 percent) ${ }^{41}$

e) Basing its program on the oversimplification of complex problems, ${ }^{42}$ focusing on a limited set of themes (including neo-environmentalism, anti-establishment and moralising discourse, guaranteed income, direct democracy through the internet), making populist appeals, clearly indicating its "enemies" (traditional parties, 10 politicians and journalists), and avoiding taking stances on sensitive issues like immigration and foreign policy. As for the latter, Dehousse noted that

international issues were conspicuously absent ... on various occasions, Grillo claimed to be against retaining the Euro at all costs, and even proposed a referendum on this issue. In other words, in line with the movement's emphasis on local issues, European integration was perceived as a constraint rather than as an opportunity. ${ }^{43}$

According to Diamanti Grillo mixed two different elements as he "'nationalised' local movements on 'common goods' and nationalist and anti(European) resentment". ${ }^{44}$

\section{The FSM and anti-establishment parties in Europe}

Although the FSM's success has been mostly unexpected, other European countries have also experienced changes in their party system recently with the emergence of more or less successful anti-establishment political parties. The economic crisis opened a window of opportunity for political outsiders in many European democracies. However, these opportunities have been taken by different political entrepreneurs in different countries: already existing fringe parties, such as the UKIP in UK and Golden Dawn in Greece, but also new political parties that have emerged since 2004, such as Syriza in Greece, the Piraten Partei (PP) and Alternative für Deutschland (AfD) in Germany. Although these parties have some features in common they also display important differences and cannot be considered as forming a 30 new party family.

The Piraten Partei (formed in September 2006 in Berlin) is probably the political actor that is most similar to the FSM for its use of the internet as organisational instrument, its emphasis on participatory democracy, its political positioning beyond left and right and its anti-elitism. ${ }^{45}$ However, it is distinct from Grillo's party in that it is not based on a charismatic leadership and hierarchical decisionmaking. While party leadership has changed frequently in the PP since its foundation, the FSM could probably not survive as a party with mass support without

\footnotetext{
${ }^{41}$ Diamanti, "Una mappa della crisi”, xvii-xix.

${ }^{42}$ Corbetta, "Web-populismo dal destino incerto".

${ }^{43}$ Dehousse, "Negative Europeanisation".

${ }^{44}$ Diamanti, "Una mappa della crisi”, xvi.

${ }^{45}$ Hartleb, "Digital campaigning and anti-elitism".
} 
Grillo. Moreover, in the PP strategic decisions are not made through the internet but in open and frequent face-to-face assemblies that anyone is free to attend. In the FSM, the political strategy is defined by only two people (Grillo and Casaleggio), who sporadically call online consultations on specific topics (selection of candidates for elections and expulsion of dissidents).

The other parties are different from the FSM in that they tend to position themselves on the left-right cleavage: AfD, UKIP and Golden Dawn on the right and far right and Syriza on the far left. Nonetheless, one common trait of all these parties is their anti-establishment rhetoric and their criticism of the European monetary union. All tend to protest against the current (mal)functioning of representative democracy at the national and European level and a few of them are similar in terms of their conception of democracy: Syriza, the PP and the FSM call for direct participation of citizens in political processes and claim that representative democracy could be improved (and even overcome) by "injections" of direct democratic practices. However, important differences between democratic visions and real practices have emerged: both PP and FSM have had problems in making such claims effective. These problems are related to their democratic procedures. Because of its horizontal organisation, the PP's leaders are relatively powerless and often criticised by members as the party is based on an assemblarian model that has proved chaotic and ineffective. The FSM, on the other hand, does not convene general assemblies, reserving participation for registered members and limiting it to sporadic online consultations.

The other anti-establishment parties do not present particular innovations from the point of view of their democratic conceptions and practices.

Significant differences among these parties can also be found in their manifestos: most of them sprang up around single issues neglected by existing parties - FSM (the environment), PP (internet freedom and privacy), UKIP (euro-scepticism) etc. - and have broadened their thematic focus over time.

Finally, scholars have questioned whether the FSM belongs to the family of neopopulist parties. Some have stressed features (such as direct appeal to the people, oversimplification of complex problems, Manichean vision of reality, charismatic leadership etc.) that would clearly qualify it as populist, ${ }^{46}$ while others have underlined specific traits (such as emphasis on direct participation and civic engagement, a different social base, etc.) that would make it quite distinct ${ }^{47}$. Be that as it may, populist parties tend to emerge during the (economic, political and moral) crises of democratic regimes. It has been noted that in these phases they suddenly become attractive and successful, but because they fail to come through on their promises

\footnotetext{
${ }^{46}$ Corbetta, "Web-populismo dal destino incerto".

${ }^{47}$ Biorcio and Natale, Politica a 5 stelle.
} 
and because they lack government experience, they generally decline just as quickly. ${ }^{48}$

\section{Falling stars?}

This article has focused on the contextual characteristics that generated a window of opportunity for Grillo's party, namely economic crisis, austerity measures and corruption scandals. Four different phases in the life of the movement have been discussed: from latency and invisibility on the internet (2005-07), to mass rallies (2007-08), from the entry into the electoral arena (2008-11) to the electoral boom and institutionalization (since 2012). Among the reasons for Grillo's success are the movement's particular communication strategies, internet-based organisation, political positioning beyond left and right and restricted thematic focus.

The FSM's future prospects are related to contextual changes as well as to the party's specific inner developments. ${ }^{49}$ On the one hand, the capacity of the Italian party system to reform itself will determine the opportunities for the movement and, on the other, the FSM's ability to prove its capacity to govern, to keep an extremely heterogeneous constituency united and to identify the proper means to deal with dissent will define its future development.

The issue of internal democracy and management of dissent is a particularly delicate one. The online primaries held in December 2012 to select the movements' candidates for parliament were very problematic in terms of participation, inclusivity and transparency. ${ }^{50}$ Only after reiterated pressure from FSM members and journalists did Grillo display the overall number of participants in the election $(20,252)$. However, data on votes gained during these primaries by individual candidates (on average 133 each) have never been made public. The entire electoral process was managed by Grillo's staff. No form of external control was possible, which means that data could easily have been manipulated.

Concerning the movement's effectiveness in representative institutions, problems have surfaced both at the national and the local level. The sizeable numerical presence in the national parliament have not yet translated into significant policy proposals as most attention was initially focused on cuts in MPs' salaries and expulsion of dissidents. Concerning local governments, the case of the city of Parma is very telling. During the electoral campaign, Grillo promised that, in case of a victory of the FSM, the ongoing construction of an incinerator would be stopped. One year later, the incinerator was finally built and came into operation. The difficult financial situation inherited by the previous administration has been dealt with by raising municipal taxes and the cost of social services.

\footnotetext{
${ }^{48}$ Taggart, Populism; Mény and Surel. Democracies and the Populist Challenge.

${ }^{49}$ Bordignon and Ceccarini, "Five Stars and a Cricket".

${ }^{50}$ Mosca, Vaccari and Valeriani, "Le 'parlamentarie' del 5 stelle".
} 
Another problematic aspect concerns the relation between Grillo and movement's representatives. Some of them have been expelled because they denounced the lack of internal democracy and criticised the leader. A proposal concerning the abolition of the law making illegal entry into the country a crime put forward in parliament by two of the movement's MPs were declared by Grillo and Casaleggio as "solely personal ... because a spokesperson cannot assume the right to make such an important decision in relation to an issue that is of such concern socially, without have prior consultation with people". ${ }^{1}$ Grillo deliberately avoids tackling divisive issues like immigration which could easily split his extremely diverse electorate.

Criticism of Grillo's posts expressed on his blog are often removed by his staff even if they are made by certified users and are not expressed in offensive language. Critical comments have been attributed to "hordes of trolls, of fakes, of multi-nicks" and defined as "squirts of digital shit". 52

After postponing it several times, at the end of October 2013, Grillo and his staff launched the "operative system", an online platform that should allow registered users to interact with the movement's MPs to amend existing bills and propose new legislation. This could be seen as an effort to engage members in the institutional process of law formation. However, reading, managing and merging thousands of comments on this online platform and accommodating them in an institutional framework will not be an easy task.

Thus, the future development and prospects of the movement will depend on its capacity to address the issue of internal democracy adequately and provide effective responses to the desire for participation expressed by a significant part of its supporters.

\section{References}

Bimber, B. Information and American Democracy: Technology in the Evolution of Political Power. Cambridge, New York: Cambridge University Press, 2003.

Biorcio, R. and Natale, P. Politica a 5 stelle. Idee, storia e strategie del movimento di Grillo. Milano: Feltrinelli, 2013.

Bordignon, F. and L. Ceccarini. "Five Stars and a Cricket. Beppe Grillo Shakes Italian Politics". South European Society and Politics, 2013.

Bordignon, F. and L. Ceccarini. “'Tsunami' a 5 stelle”. In Un salto nel voto. Ritratto politico dell'Italia di oggi, edited by I. Diamanti, F. Bordignon and L. Ceccarini: 60-71. Rome: Laterza, 2013.

Boyer, D. "Simply the Best: Parody and Political Sincerity in Iceland". American Ethnologist 40, no. 2 (2013): 276-87.

Carbone, M. and J.L. Newell. "The (apparent) calm after the storm". Contemporary Italian Politics 5, no. 2 (2013): 103-5.

\footnotetext{
${ }^{51} \mathrm{http}: / / \mathrm{www}$. beppegrillo.it/en/2013/10/the_crime_of_clandestinity.html.

${ }^{52}$ http://www.beppegrillo.it/en/2013/03/squirts_of_digital_shit.html.
} 


\section{L. Mosca}

Corbetta, P. "Un web-populismo dal destino incerto". In Il partito di Grillo, edited by P. Corbettaand

E. Gualmini: 197-214. Bologna: il Mulino, 2013.

Crouch, C. Post-democracy. Cambridge: Polity Press, 2005.

Dehousse, R. "Negative Europeanisation: European issues in the Italian elections". Contemporary Italian Politics 5, no. 2 (2013): 166-78.

Diamanti, I. "Una mappa della crisi della democrazia rappresentativa". ComPol 1 (2013): 3-16.

10 Fella, S., and C. Ruzza. "Populism and the Fall of the Centre-Right in Italy: The End of the Berlusconi Model or a New Beginning?" Journal of Contemporary European Studies 21, no. 1 (2013): 38-52.

Fornaro, F. "Un non-partito: il Movimento 5 stelle". il Mulino 2 (2012): 253-61.

Grillo, B. and G. Casaleggio. Siamo in guerra. Per una nuova politica. Milan: Chiarelettere, 2011.

Gualmini, E. "Introduzione. Da movimento a partito". In Il partito di Grillo, edited by P. Corbettaand E. Gualmini: 7-28. Bologna: il Mulino, 2013.

Hartleb, F. "Digital campaigning and the growing anti-elitism: the Pirates and Beppe Grillo". European View 12, no. 1 (2013): 135-42.

Karpf, D. The MoveOn Effect: The Unexpected Transformation of American Political Advocacy. New York: Oxford University Press, 2012.

Lanfrey, D. "Il MoVimento dei grillini tra meetup, meta-organizzazione e democrazia del monitoraggio". In Nuovi media, nuova politica? Partecipazione e mobilitazione online da MoveOn al MoVimento 5 stelle, edited by L. Mosca, and C. Vaccari: 143-66. Milan: FrancoAngeli, 2011.

Lanzone, L. "Dai Meetup al Parlamento. Candidati ed eletti del Movimento 5 Stelle". il Mulino 4 (2013): 732-8.

Manin, B. The principles of representative government. Cambridge: Cambridge University Press, 1997.

Mazzoleni, G., and W. Schulz. "'Mediatization' of Politics: A Challenge for Democracy?" Political Communication 16, no. 3 (1999): 247-61.

Mény, Y., and Y. Surel (eds). Democracies and the Populist Challenge. London: Macmillan, 2002.

Mosca, L. La webpolitica. Istituzioni, candidati, movimenti fra siti, blog e social network. (second edition) Firenze: Le Lettere, 2013.

Mosca, L. "A year of social movements in Italy: from the No-Tavs to the five-star movement". In Italian Politics 2012, edited by A. di Virgilio, and C. Radaelli. New York: Berghahn, 2013.

Mosca, L. and C. Vaccari. "Il Movimento e la rete". In Il partito di Grillo, edited by P. Corbettaand E. Gualmini: 169-96. Bologna: il Mulino, 2013.

Mosca, L., C. Vaccari and A. Valeriani, . "Le 'parlamentarie' online del movimento 5 stelle: sconosciuti alla ribalta". Press release of the Istituto Cattaneo. http://www.cattaneo.org/images/ comunicati_stampa/AnalisiCattaneo_Parlamentarie_M5S_19dicembre2012.pdf.

Natale, P. "Il comportamento elettorale: la fedeltà leggera". In Il maggioritario regionale. Le elezioni del 16 aprile 2000, edited by A. Chiaramonte and R. D’Alimonte: 157-74. Bologna: il Mulino, 2000.

Norris, P. A virtuous circle: Political communications in post-industrial societies. New York: Cambridge University Press, 2000.

Passarelli, G., F. Tronconi and D. Tuorto, . "Dentro il Movimento: organizzazione, attivisti e programmi”. In Il partito di Grillo, edited by P. Corbettaand E. Gualmini: 123-67. Bologna: il Mulino, 2013.

Pinto, R., and L. Vignati. "Il successo e i dilemmi del Movimento 5 Stelle". il Mulino 4 (2012): 731-8.

50 Taggart, P.A. Populism. Philadelphia: Open University Press, 2000. 
Tronconi, F. “The Italian regional elections of March 2010. Continuity and a few surprises”. Regional and Federal Studies 20, no. 4-5 (2011): 577-86.

Vignati, R. "The challenge of the five-star movement". In Italian Politics 2012, edited by A. di Virgilio, and C. Radaelli. New York: Berghahn, 2013. 